\title{
Control of the concentration of Radon in the air of the underground tunnels of Sidra Ltd. (applied research: step one)
}

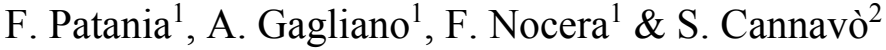 \\ ${ }^{I}$ Department of Industrial Engineering (D.I.I.), \\ Catania University, Sicily \\ ${ }^{2}$ Independent Researcher, Acicastello (CT), Sicily
}

\begin{abstract}
Radon (Rn) is a colourless, odourless and flavourless gas that, in closed environments, can reach high concentrations. Sometimes, it's descending radioactive isotopes release high radioactive particles during decay, which own such penetration powers to be able to sometimes damage the bronchial epithelium of people breathing in the air when there is a high Rn concentration. This paper concerns the technical-scientific procedures used to achieve the reduction of $\mathrm{Rn}$ concentrations in the tunnels of Sidra Ltd., to create safe working conditions for the operators inside these tunnels.
\end{abstract}

Keywords: radon, tunnel, air pollution, techniques.

\section{Introduction}

Sidra Ltd. is a company shared by the Municipal Agency, which extracts, channels and supplies water to almost all inhabitants of Catania.

The company has two underground tunnels, five kilometers long, named, respectively, "Turchio" and "Tavolone", both at about $110 \mathrm{~m}$ underground-line, where water is extracted by artesian well flows (fig. 1).

It has been noticed that inside tunnels with a high concentration of the gas Radon $(\mathrm{Rn})$ are very dangerous for workers during their activities of maintenance and management. 

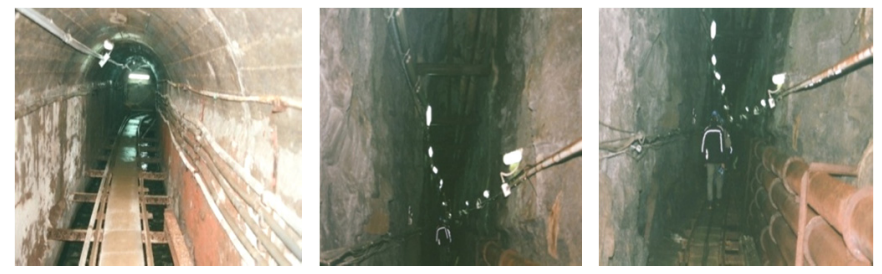

Figure 1: The tunnels 'Tavolone' and 'Turchio'.

The Energy and Environmental Section of Industrial Engineering Department (DII) of Catania University has been commissioned by Sidra Ltd. to study and realize suitable control work to reduce the $\mathrm{Rn}$ concentrations and to permanently reach $\mathrm{Rn}$ values that are not noxious for the health of operators. This paper illustrates the chosen technical-scientific procedures to achieve the reduction of $\mathrm{Rn}$ concentrations. The procedures are carried out as follows:

- measurements of concentrations of $\mathrm{Rn}$ in the air and in the water of tunnels are taken in subsequent periods of time to identify the main source of gas and a real trend of the $\mathrm{Rn}$ pollution;

- the selection of better techniques and equipment to reduce indoor $\mathrm{Rn}$ concentrations;

- the planning and positioning of chosen equipment along the tunnels;

- the checking of operational results to verify the reduction of Rn concentrations.

\section{The dangers of Radon (Rn)}

$\mathrm{Rn}$ is a natural gas, originating from the radioactive decay of the isotope Ra-226, which, in turn, originated from consecutive decays of the progenitor U-238.

In the natural environment, $\mathrm{Rn}$ is present in the crustal plate and in body of water too, with concentrations ranging between 1.0 and $2.8 \mathrm{ppm}$ and with "halflives" of 3.82 days.

The concentrations of $\mathrm{Rn}$ in the open-air varies between 8.0 and $50.0 \mathrm{~Bq} / \mathrm{m}^{3}$ but in the case of all sorts of indoor-air volumes it may be much higher due to Rn's accumulations. $\mathrm{Rn}$ is a "noble gas" and for this reason it is neither reactive nor hazardous to health when it is inhaled with air and expelled during average times of breathing. The dangerousness, on the other hand, is caused by radioactive decay of Rn's descending radioactive isotopes Po-218 and Po-214, since they have compatible times of decaying with the retention of breathing air in the lungs of people. During decay, both Po-218 and Po-214 give out particles $\alpha$ and $\beta$ with high a radioactive energy. In particular, the alpha particles possess a tremendous penetrating power that allows to particles to arrive and to damage the DNA of bronchial epithelium. The low value of $\mathrm{Rn}$ 's concentrations means that consequently low numbers of $\alpha$ particles damage DNA and, in this case, there is the biological self-remedial action of damage.

The high value of Rn's concentrations, to the contrary, produces high numbers of $\alpha$ particles damaging in irreversible way DNA and creating a focus on lung cancer. 


\section{Some information about Italian's regulations}

In Italy, regulatory norms make reference to "absorbed doses" (mSv/year). The value of "absorbed dose" is correlated to Rn concentrations in air and to times of exposure of worker in indoor volume.

In particular, in the case of people working in underground spaces with periods of activity greater than ten hours per month then the manager is enforced by regulation to periodically control the value of the "absorbed dose" of workers. Each time that the inspected values of "absorbed dose" results are greater than $3 \mathrm{mSv} / \mathrm{year}$, then the owner is forced to put to use any technical interventions of remedy that are able to reduce the Rn concentrations in working places.

For Italian regulations, the survey must be carried out by a "Qualified Technician" (QT). The QT of Sidra Ltd. carried out measurements by means of a passive detector, briefly referred to as "canisters" at activated carbons and by means of an "active detector", named "Lucas cells" (fig. 2). The measured values are shown in Table 1.
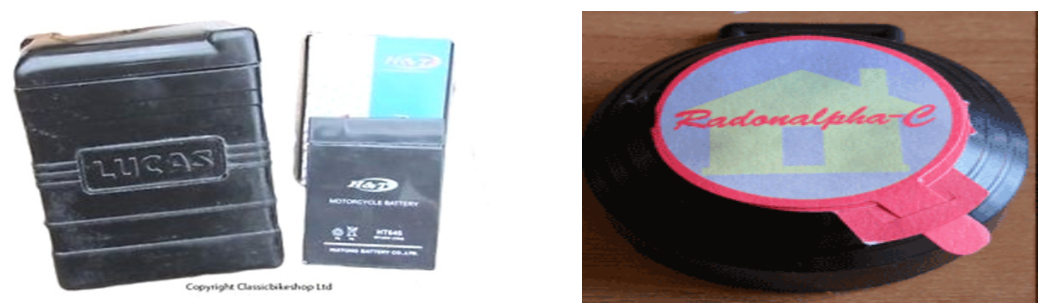

Figure 2: Rn detectors.

Table 1: $\quad$ Some measurements of $\mathrm{Rn}$ concentrations (TAV= Tavolone; TURC $=$ Turchio) .

\begin{tabular}{|l|l|l|l|l|}
\hline $\begin{array}{l}\text { Rilevation } \\
\text { point }\end{array}$ & Equipment & Starting of survey & Stop of survey & $\begin{array}{l}\text { Rn's concentrations } \\
{\left[\mathbf{B q} / \mathbf{m}^{3}\right]}\end{array}$ \\
\hline $\mathrm{N}^{\circ}$ 9/TAV & Passive dosimeter & $06 / 17 / 2013$ & $09 / 11 / 2013$ & $18000 \pm 2000$ \\
\hline $\mathrm{N}^{\circ} 10 / \mathrm{TAV}$ & “ & $06 / 17 / 2013$ & $09 / 11 / 2013$ & $>19000$ \\
\hline $\mathrm{N}^{\circ} 11 / \mathrm{TAV}$ & “ & $06 / 17 / 2013$ & $09 / 11 / 2013$ & $17000 \pm 2000$ \\
\hline $\mathrm{N}^{\circ} 14 / \mathrm{TAV}$ & “ & $06 / 18 / 2013$ & $09 / 11 / 2013$ & $17000 \pm 2000$ \\
\hline $\mathrm{N}^{\circ}$ 8/TAV & “ & $06 / 17 / 2013$ & $09 / 11 / 2013$ & $16000 \pm 1900$ \\
\hline $\mathrm{N}^{\circ} 15 / \mathrm{TAV}$ & “ & $06 / 18 / 2013$ & $09 / 11 / 2013$ & $16000 \pm 1900$ \\
\hline $\mathrm{N}^{\circ}$ 4/TURC & “ & $06 / 14 / 2013$ & $09 / 06 / 2013$ & $>19000$ \\
\hline $\mathrm{N}^{\circ}$ 5/TURC & “ & $06 / 14 / 2013$ & $09 / 06 / 2013$ & $>19000$ \\
\hline $\mathrm{N}^{\circ}$ 3/TURC & “ & $06 / 14 / 2013$ & $09 / 06 / 2013$ & $>19000$ \\
\hline $\mathrm{N}^{\circ}$ 8/TURC & “ & $06 / 14 / 2013$ & $09 / 06 / 2013$ & $>19000$ \\
\hline $\mathrm{N}^{\circ}$ 9/TURC & “ & $06 / 14 / 2013$ & $09 / 06 / 2013$ & $>19000$ \\
\hline $\mathrm{N}^{\circ}$ 7/TURC & “ & $06 / 14 / 2013$ & $09 / 06 / 2013$ & $>19000$ \\
\hline
\end{tabular}

Additional measurements showed negligible values of Rn concentrations in the water of tunnels: that means gas is coming exclusively from the ground. 


\section{The choice among various solutions}

The scientific methods used to control and mitigate gas pollution [1] in this kind of indoor space usually recommend the following solutions:

1. the waterproofing of inner surfaces of tunnels to impede access of Rn;

2. the producing of a back-pressure into volumes of tunnels so as to repulse actual air flow coming from ground;

3. the producing of a partial or complete renewal of air in tunnels such as to remove the $\mathrm{Rn}$ accumulations.

The First solution necessitates to water-proof about $25,000 \mathrm{~m}^{2}$ of irregular and rough surfaces: it means excessive initial investment and subsequent high cost of maintenance. Furthermore, it is very hard to waterproof surfaces related about 2,500 $\mathrm{m}$ of tunnels not accessible as lacking of walkway and lighting too. And finally, it is quite impossible to waterproof the canals at the foot of tunnels where the water flows. This solution demands remarkable costs of intervention, maintenance and excessive times of construction of remedies too. For these reasons, this solution has been rejected.

The Second solution disallows the proper solution of the problem since the tunnels present many gaps in the inner surfaces of walkable areas and certainly more and more gaps in areas that are impossible to be inspected. Moreover, there are, along the tunnels, the same maintenance rooms and one elevator stairwell (fig. 3).
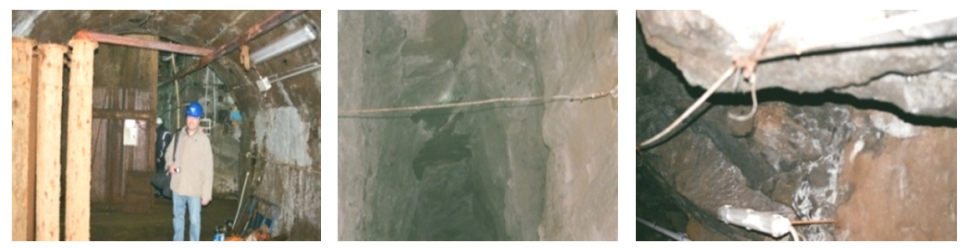

Figure 3: Maintenance rooms and gaps.

The inspection of surfaces assures that many gaps and the elevator stairwell are in direct contact with the outdoor environment. The morphological structure of volumes and the presence of gaps means that we must take into consideration the following points:

- it is very difficult to maintain back-pressure in tunnels because of physical connections between indoor and outdoor environment through the leaks;

- it is very difficult to evaluate the global fluid-dynamic load resistance so to try back-pressure to give to air in tunnels: it means uncertainty in choosing model of fans that must maintain back-pressure. More, in this solution fans would work continuously for the whole hours of the day otherwise it could be recreated air flow toward the inside without resolution of $\mathrm{Rn}$ accumulations. The aforementioned considerations mean uncertainty in design of fans that would work during the whole day causing an increasing of energy management 
costs, more the Authors believe this solution not able to guarantee removal of Rn's accumulations. For these reasons, this solution has been rejected.

The third solution appears to face the problem in the right way on the basis of the following considerations:

- it is possible calculate the fluid-dynamic load losses of flow rate able to obtain the complete replacement of air within tunnels when the value of velocity of air in the smallest cross-section during the time of replacement is $1.5 \mathrm{~m} / \mathrm{s}$. The limit of $1.5 \mathrm{~m} / \mathrm{s}$ has been chosen to have times of replacement compatible with the staying of workers within tunnels;

- the knowledge of the biggest fluid-dynamic load losses allows to select in right way powers and type of fans to use to have the right replacement of air;

- it is possible to design an electronic control system that, by mean of detectors of Rn's concentrations (fig. 4), is able to start or to stop the operation of each fan positioned along tunnels.

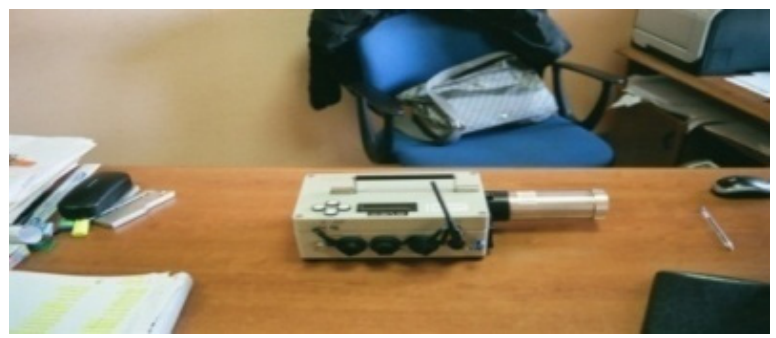

Figure 4: Electronic detector of control system.

The chosen solution has the following benefits:

- the certainty of removal of Rn accumulations in compatible times with staying of workers in tunnels: in this way Authors promise all insurances for worker's health;

- surely energy saving since each fan works not continuously but only when there are dangerous Rn's concentrations in section of tunnel where it is situated: it means low cost of handling and maintenance;

- estimated costs for realization of whole system are certainly lower than that required for the other solutions also because Sidra Ltd. has indeed possession in stock of same fans that, after verification, must could be adequate for our purposes.

\section{Procedure to calculate cross-sections $\mathbf{A}_{\mathbf{j}}$}

Tunnels don't have constant cross-sections along their global length and for this reason people wishing to obtain fluid-dynamic loads followed a standard computation procedure, based on:

- the partition of the tunnel's length in discrete segment $T_{i}$ each of them having homogeneous cross-section;

- the utilization of weighted average for all calculus of variation of parameters. 
The entire computation procedure turn out very articulate and it cannot be exposed in full for room reason in present paper but it will be available on request from the authors. The main parameters and formulas are shown in the following points:

- $\quad T_{i}=$ segment of tunnel's length having area of cross-section $S_{i p}\left[\mathrm{~m}^{2}\right]$ each not differing more than $30 \%$ from the other;

- $A_{i}^{\prime}=\frac{\sum_{p=1}^{n_{i}-1} s_{i p} \cdot l_{i p}}{\sum_{p=1}^{n_{i}-1} l_{i p}}=$ weighted average of real areas of cross-sections of $S_{i p}$

$\mathrm{T}_{\mathrm{i}}$ where: $\mathrm{S}_{\mathrm{ip}}=$ real area of cross-section of $\mathrm{T}_{\mathrm{i}}$ and $\mathrm{l}_{\mathrm{ip}}=$ real distance between Sip and $\mathrm{S}_{\mathrm{i}}(\mathrm{p}+1)$;

- $\mathrm{C}_{\mathrm{j}}=$ "class of cross-section" $(\mathrm{j}=0,1,2,3 \ldots)$ that is a continuous set of areas of cross-sections $\mathrm{C}^{\mathrm{j}}=[\mathrm{j}, \mathrm{j}+1]$

- the $\mathrm{C}_{\mathrm{j}}$, fixed the interval, allows to identify every $\mathrm{n}_{\mathrm{j}}$ areas $A_{i}^{\prime}$ of cross-sections in such a manner that $\mathrm{j}\left[\mathrm{m}^{2}\right] \leq A_{i}^{\prime}<\mathrm{j}+1\left[\mathrm{~m}^{2}\right]$;

- the areas of the fixed interval $\mathrm{C}_{\mathrm{j}}$ are called $A_{j p}^{\prime}$

- $\mathrm{A}_{\mathrm{j}}=\frac{\sum_{p=1}^{n_{j}} A_{j p}^{\prime} \cdot l_{j p}}{\sum_{p=1}^{n_{j}} l_{j p}}=$ weighted average of $A_{j p}^{\prime}$ where: $A_{j p}^{\prime}=$ generic area of $\mathrm{C}_{\mathrm{j}}$ class of cross-sections;

- $\mathrm{l}_{\mathrm{jp}}=$ length of segment of tunnel where $A_{j p}^{\prime}$ is located.

\section{Procedure to calculate geometrical parameters of $\mathbf{A}_{\mathbf{j}}$}

Naming $S_{i p}^{\prime}$ the $S_{i p}$ of generic $T_{i}$ net of area enclosed between walk-able surface and underlying flowing water surface, that is the real area of air flowing, people calculated for each $S_{i p}^{\prime}$ :

- pip = "wet perimeter" of $S_{i p}^{\prime}$ in the case of air wet perimeter pip coincides with geometrical perimeter of $S_{i p}^{\prime}$;

- $\operatorname{dip}=$ "geometrical parameter" of $S_{i p}^{\prime}: \operatorname{dip}=\frac{4 s_{i p}^{\prime}}{\mathrm{p}_{i p}}$.

For each segment $T_{i}$ people calculated:

- $d_{i}^{\prime}=$ "geometrical parameter" of $A_{i}^{\prime}$ as weighted average $d_{i p}$;

- $d_{i}^{\prime}=\frac{\sum_{p=1}^{n_{i}-1} d_{i p} \cdot l_{i p}}{\sum_{p=1}^{n_{i}-1} l_{i p}}$ where lip distance between $S_{i p}^{\prime}$ and subsequent $S_{i}^{\prime}(\mathrm{p}+1)$.

For each class of cross-sections $\mathrm{C}_{\mathrm{j}}=[\mathrm{j}, \mathrm{j}+1]$ people identified $\mathrm{n}_{\mathrm{j}}$ "geometrical parameters" $d_{j p}^{\prime}$ of $\mathrm{n}_{\mathrm{j}}$ areas $A_{j p}^{\prime}=\mathrm{n}_{\mathrm{j}}$ "geometrical parameters" $d_{i}^{\prime}$ corresponding to $\mathrm{n}_{\mathrm{j}}$ cross-sections $A_{i}^{\prime}$ in such manner that $\mathrm{j}\left[\mathrm{m}^{2}\right] \leq A_{i}^{\prime}<\mathrm{j}+1\left[\mathrm{~m}^{2}\right]$ in the way to have $\mathrm{d}_{\mathrm{j}}$ "geometrical parameter" of $\mathrm{A}_{\mathrm{j}}$ as weighted average of "geometrical parameters" $d_{j p}^{\prime}$ : 
$-\mathrm{d}_{\mathrm{j}}=\frac{\sum_{p=1}^{n_{j}} d_{j p}^{\prime} \cdot l_{j p}}{\sum_{p=1}^{n_{j}} l_{j p}}$ where $\mathrm{l}_{\mathrm{jp}}=$ length of segment of tunnel where $A_{p}^{\prime}$ is located.

\section{Procedure to calculate the acceptable air flow rate}

The "acceptable air flow rate" $\left(\mathrm{Q}_{\mathrm{amm}}\right)$ is the flow-rate that will maintain air velocity, predetermined by planning in each cross-sections $A_{j}$, higher than $v_{\min }(1.5 \mathrm{~m} / \mathrm{s})$ and lower than $v_{\max }(4.00 \mathrm{~m} / \mathrm{s})$. The higher limit of $4.0 \mathrm{~m} / \mathrm{sec}$ has been chosen to avoid possible damages caused by air velocity to maintenance and safety equipment and to electrical and electronic fitting too. The procedure of computation is as follows:

- $\mathrm{Qj}_{\min }$ is air flow rate passing through cross-section $\mathrm{A}_{\mathrm{j}}$ at lower limit of velocity;

- $\mathrm{V}_{\min }=1.5 \mathrm{~m} / \mathrm{s}$, various air flow rates are calculated by the formula: $\mathrm{Qj}_{\min }=$ $A j v_{\min } \mathrm{j}=0,1,2, \ldots . \mathrm{k}$ (Table 2).

Table 2: Tavolone and Turchio: acceptable air flow rate $\left(\mathrm{Q}_{\mathrm{amm}}\right)$.

\begin{tabular}{|c|c|c|c|c|c|c|c|c|}
\hline & \multicolumn{8}{|c|}{ Tavolone tunnels } \\
\hline & $A_{j}$ & $\mathrm{~V}_{\min }$ & $\mathrm{Q}_{\text {jmin }}$ & $v_{\text {max }}$ & $\mathrm{Q}_{\text {imax }}$ & \multicolumn{2}{|c|}{$\mathrm{Q}_{\mathrm{jamm}}$} & $\mathbf{Q}_{\mathrm{amm}}$ \\
\hline & $\left(\mathrm{m}^{2}\right)$ & $(\mathrm{m} / \mathrm{s})$ & $\left(\mathrm{m}^{3} / \mathrm{s}\right)$ & $(\mathrm{m} / \mathrm{s})$ & $\left(\mathrm{m}^{3 / 3} / \mathrm{s}\right.$ & \multicolumn{2}{|c|}{$\left(\mathrm{m}^{3} / \mathrm{s}\right)$} & $\left(\mathrm{m}^{3} / \mathbf{s}\right)$ \\
\hline I & 2.80 & \multirow{4}{*}{1.5} & 4.20 & \multirow{4}{*}{4} & 11.20 & \multirow{2}{*}{\multicolumn{2}{|c|}{$\frac{[4.20 ; 11.20]}{[5.17: 13.80]}$}} & \multirow{4}{*}{9} \\
\hline II & 3.45 & & 5.17 & & 13.80 & & & \\
\hline III & 4.17 & & 6.25 & & 16.68 & \multicolumn{2}{|c|}{$\frac{[5.17 ; 13.80]}{[6.25 ; 16.68]}$} & \\
\hline IV & 5.52 & & 8.28 & & 22.08 & \multicolumn{2}{|c|}{$[8.28 ; 22.08]$} & \\
\hline & \multicolumn{7}{|c|}{ Turchio tunnels } & \\
\hline & $\mathrm{A}_{\mathrm{j}}$ & $\mathrm{V}_{\min }$ & $\mathrm{Q}_{\text {imin }}$ & $v_{\text {max }}$ & $\mathrm{Q}_{\max }$ & $\mathrm{Q}_{\mathrm{jamm}}$ & $\mathbf{Q}_{\mathrm{amm}}$ & \\
\hline & $\left(\mathrm{m}^{2}\right)$ & $(\mathrm{m} / \mathrm{s})$ & $\left(\mathrm{m}^{3} / \mathrm{s}\right)$ & $(\mathrm{m} / \mathrm{s})$ & $\left(\mathrm{m}^{3} / \mathrm{s}\right)$ & $\left.\left(\mathrm{m}^{3} / \mathrm{s}\right)\right)$ & $\left(\mathrm{m}^{3} / \mathbf{s}\right)$ & \\
\hline I & 2.83 & \multirow{8}{*}{1.5} & 4.24 & \multirow{8}{*}{4} & 11.32 & {$[4.24 ; 11.32]$} & \multirow{8}{*}{9} & \\
\hline II & 3.19 & & 4.78 & & 12.76 & {$[4.78 ; 12.76]$} & & \\
\hline II & & & & & & & & \\
\hline bis & 4.09 & & 6.13 & & 16.36 & {$[6.13 ; 16.36]$} & & \\
\hline III & 5.17 & & 7.75 & & 20.68 & {$[7.75 ; 20.68]$} & & \\
\hline IV & 6.60 & & 9.9 & & 26.4 & {$[9.9 ; 26.4]$} & & \\
\hline $\mathrm{V}$ & 9.3 & & 13.95 & & 37.2 & {$[13.95 ; 37.2]$} & & \\
\hline VI & 15.73 & & 23.59 & & 62.92 & {$[23.59 ; 62.92]$} & & \\
\hline
\end{tabular}

- $\mathrm{Qj}_{\max }$ is air flow rate that passing through cross-section $\mathrm{A}_{\mathrm{j}}$ at upper limit of velocity vmax $=4.0 \mathrm{~m} / \mathrm{s}$, various air flow rates are calculated by formula: $Q \mathrm{j}_{\max }$ $=A j v_{\text {maxj }}=0,1,2 \ldots . . \mathrm{k}$ (Table 2);

- the acceptable air flow rate in every $A_{j}$ is that one producing the velocity $v_{j}$ in such a manner that $\mathrm{v}_{\min } \leq \mathrm{v}_{\mathrm{j}} \leq \mathrm{v}_{\max }$ and consequently: $\mathrm{Qj}$ min $\leq \mathrm{Q}_{\mathrm{amm}} \leq \mathrm{Qj} \mathrm{j}_{\operatorname{maxj}}=$ $0,1,2 \ldots . . . \mathrm{k}$ (Table 2);

- on varying $\mathrm{A}_{\mathrm{j}}$ people obtained corresponding $\mathrm{v}_{\mathrm{j}}$ by the formula: $\mathrm{v}_{\mathrm{j}}=\frac{Q_{a m m}}{A_{j}}$;

- the computation of Reynold's number for each $A_{j}$ is given by the formula: $R_{e j}=$ $\frac{\rho_{a u} \cdot v_{j} \cdot d_{j}}{\mu_{a u}}$ where $\rho_{\mathrm{au}}=$ density of wet air and $\mu_{\mathrm{au}}=$ kinematic viscosity of wet air. 
The computations of Reynold's numbers guarantee the turbulent motion of air in every cross-section $\mathrm{A}_{\mathrm{j}}$ (Table 3 ).

Table 3: Tavolone and Turchio: Velocity and Reynold's number in $\mathrm{A}_{\mathrm{j}}$ crosssection of class sections $C_{j}$ for flow rate $Q_{a m m}=9 \mathrm{~m}^{3} / \mathrm{s}$.

\begin{tabular}{|c|c|c|c|c|c|c|}
\hline & \multicolumn{6}{|c|}{ Tavolone tunnels } \\
\hline & $A_{j}$ & $\mathrm{~d}_{\mathrm{j}}$ & & $\mathbf{v}_{\mathbf{j}}$ & $\mathbf{R e}_{j}$ & Typology of motion \\
\hline & $\left(\mathrm{m}^{2}\right)$ & (m) & & $(\mathrm{m} / \mathbf{s})$ & & \\
\hline I & 2.8 & 1.57 & & 3.21 & $3.50 \cdot 10^{5}$ & Turbulent \\
\hline II & 3.45 & 1.78 & & 2.61 & $3.23 \cdot 10^{5}$ & Turbulent \\
\hline III & 4.17 & 1.94 & & 2.16 & $2.91 \cdot 10^{5}$ & Turbulent \\
\hline \multirow[t]{5}{*}{ IV } & 5.52 & 2.22 & & 1.63 & $2.51 \cdot 10^{5}$ & Turbulent \\
\hline & \multicolumn{2}{|c|}{$\begin{array}{l}\text { Flow rate } \\
\mathrm{Q}_{\mathrm{amm}}=9 \mathrm{~m}^{3} / \mathrm{s}\end{array}$} & \multicolumn{3}{|c|}{$\begin{array}{l}\text { Density wet air } \\
\rho_{\text {a.u. }}=1.25 \mathrm{~kg} / \mathrm{m}^{3}\end{array}$} & $\begin{array}{l}\text { Dynamic air viscosity } \\
\mu=1.80 \cdot 10^{-5} \mathrm{~Pa} \cdot \mathrm{s}\end{array}$ \\
\hline & \multicolumn{5}{|c|}{ Turchio tunnels } & \\
\hline & $A_{j}$ & $\mathrm{~d}_{\mathrm{j}}$ & $\mathbf{v}_{\mathbf{j}}$ & $\mathbf{R e}_{\mathrm{j}}$ & $\begin{array}{l}\text { Typology of } \\
\text { motion }\end{array}$ & \\
\hline & $\left(\mathrm{m}^{2}\right)$ & (m) & $(\mathrm{m} / \mathrm{s})$ & & & \\
\hline I & 2.83 & 1.56 & 3.18 & $3.44 \cdot 10^{5}$ & Turbulent & \\
\hline II & 3.19 & 1.68 & 2.82 & $3.29 \cdot 10^{5}$ & Turbulent & \\
\hline II bis & 4.09 & 1.75 & 2.20 & $2.67 \cdot 10^{5}$ & Turbulent & \\
\hline III & 5.17 & 1.99 & 1.74 & $2.40 \cdot 10^{5}$ & Turbulent & \\
\hline IV & 6.60 & 2.25 & 1.36 & $2.12 \cdot 10^{5}$ & Turbulent & \\
\hline $\mathrm{V}$ & 9.3 & 2.54 & 0.96 & $1.69 \cdot 10^{5}$ & Turbulent & \\
\hline VI & 15.73 & 3.45 & 0.57 & $1.37 \cdot 10^{5}$ & Turbulent & \\
\hline
\end{tabular}

To reach the goal of having the replacement of air in the tunnels at times that are compatible with the presence of operators and to also save energy, the following steps are taken:

- the real volumes of air contained in tunnels are computed: VTA $=10.560 \mathrm{~m}^{3}$ (Tavolone) and VTU $=13.070 \mathrm{~m}^{3}$ (Turchio);

- people selected air flow rate passing through the smallest cross-section $\mathrm{A}_{1 \text { at }}$ lower limit of velocity $\mathrm{V}_{\min }=1.5 \mathrm{~m} / \mathrm{s}$ (Table 4) resulting in: $\mathrm{Q} 1_{\min } \mathrm{TA}=4.20 \mathrm{~m}^{3} / \mathrm{s}$ (Tavolone) and $\mathrm{Q} 1_{\min } \mathrm{TU}=4.25 \mathrm{~m}^{3} / \mathrm{s}$ (Turchio);

- with elementary computations people found the time of replacement of air: $\frac{V_{T A}}{Q 1_{\min T A}}=\frac{10,560}{15,120} \frac{\mathrm{m}^{3} \mathrm{~h}}{\mathrm{~m}^{3}}=0.698 \mathrm{~h}=41.9$ minutes $\quad \frac{V_{T U}}{Q 1_{\min T U}}=\frac{13,070}{15,282} \frac{\mathrm{m}^{3} \mathrm{~h}}{\mathrm{~m}^{3}}=$ $0.855 \mathrm{~h}=51.32$ mins.

Both calculated times are largely compatible with the times of the staying of workers in tunnels. 
Table 4: Tavolone and Turchio: Velocity $v_{j k}$ in $A_{j}$ section when $Q_{k m i n}$ flows.

\begin{tabular}{|c|c|c|c|c|c|c|c|c|c|c|c|}
\hline & \multicolumn{8}{|c|}{ Tavolone tunnels } & & & \\
\hline & $\overline{A_{j}}$ & $\mathbf{Q}_{\mathrm{kmin}}$ & $\mathbf{Q}_{\mathrm{kmin}}$ & $\mathbf{Q}_{\mathrm{kmin}}$ & $\mathbf{V}_{\mathbf{j 1}}$ & $\mathrm{V}_{\mathrm{i} 2}$ & $\mathrm{~V}_{\mathrm{i} 3}$ & $\mathrm{~V}_{\mathrm{i} 4}$ & & & \\
\hline & $\left(\mathrm{m}^{2}\right)$ & $\left(\mathrm{m}^{3} / \mathrm{s}\right)$ & $\left(\mathrm{m}^{3} / \mathbf{h}\right)$ & $(\mathbf{V} / \mathbf{h})$ & $(\mathrm{m} / \mathrm{s})$ & $(\mathrm{m} / \mathrm{s})$ & $(\mathrm{m} / \mathrm{s})$ & $(\mathrm{m} / \mathrm{s})$ & & & \\
\hline I & 2.8 & 4.20 & 15120 & 1.43 & 1.50 & 1.85 & 2.23 & 2.96 & & & \\
\hline II & 3.45 & 5.18 & 18630 & 1.76 & 1.22 & 1.50 & 1.81 & 2.40 & & & \\
\hline III & 4.17 & 6.26 & 22518 & 2.13 & 1.01 & 1.24 & 1.50 & 1.99 & & & \\
\hline \multirow[t]{5}{*}{ IV } & 5.52 & 8.28 & 29808 & 2.82 & 0.76 & 0.94 & 1.13 & 1.50 & & & \\
\hline & \multicolumn{4}{|c|}{$\begin{array}{l}\text { Minimum velocity } \\
\mathrm{v}_{\min }=1.5 \mathrm{~m} / \mathrm{s}\end{array}$} & \multicolumn{4}{|c|}{$\begin{array}{l}\text { Volume of tunnel } \\
\mathrm{V}=10560 \mathrm{~m}^{3}\end{array}$} & & & \\
\hline & \multicolumn{11}{|c|}{ Turchio tunnels } \\
\hline & $A_{j}$ & $\mathbf{Q}_{\mathrm{kmin}}$ & $\mathbf{Q}_{\mathrm{kmin}}$ & $\mathbf{Q}_{\mathrm{kmin}}$ & $\mathbf{v}_{\mathbf{j} 1}$ & $\mathrm{v}_{\mathrm{j} 2}$ & $\mathrm{~V}_{\mathrm{j} 2 \mathrm{bis}}$ & $v_{j 3}$ & $\mathrm{v}_{\mathrm{j} 4}$ & $\mathrm{v}_{\mathrm{j} 5}$ & $\mathrm{v}_{\mathrm{j} 6}$ \\
\hline & $\left(\mathrm{m}^{2}\right)$ & $\left(\mathrm{m}^{3} / \mathrm{s}\right)$ & $\left(\mathrm{m}^{3} / \mathbf{h}\right)$ & $(\mathbf{V} / \mathbf{h})$ & $(\mathrm{m} / \mathrm{s})$ & $(\mathrm{m} / \mathrm{s})$ & $(\mathrm{m} / \mathrm{s})$ & $(\mathrm{m} / \mathrm{s})$ & $(\mathrm{m} / \mathrm{s})$ & $(\mathrm{m} / \mathrm{s})$ & $(\mathrm{m} / \mathrm{s})$ \\
\hline I & 2.83 & 4.25 & 15282 & 1.17 & 1.50 & 1.69 & 2.17 & 2.74 & 3.50 & 4.93 & 8.34 \\
\hline II & 3.19 & 4.79 & 17226 & 1.32 & 1.33 & 1.50 & 1.92 & 2.43 & 3.10 & 4.37 & 7.40 \\
\hline II bis & 4.09 & 6.14 & 22086 & 1.69 & 1.04 & 1.17 & 1.50 & 1.90 & 2.42 & 3.41 & 5.77 \\
\hline III & 5.17 & 7.76 & 27918 & 2.14 & 0.82 & 0.93 & 1.19 & 1.50 & 1.91 & 2.70 & 4.56 \\
\hline IV & 6.60 & 9.90 & 35640 & 2.73 & 0.64 & 0.73 & 0.93 & 1.18 & 1.50 & 2.11 & 3.58 \\
\hline $\mathrm{V}$ & 9.3 & 13.95 & 50220 & 3.84 & 0.46 & 0.51 & 0.66 & 0.83 & 1.06 & 1.50 & 2.54 \\
\hline \multirow[t]{2}{*}{ VI } & 15.73 & 23.60 & 84942 & 6.50 & 0.27 & 0.30 & 0.39 & 0.49 & 0.63 & 0.89 & 1.50 \\
\hline & \multicolumn{4}{|c|}{$\begin{array}{l}\text { Minimum velocity } \\
\mathrm{V}_{\min }=1.5 \mathrm{~m} / \mathrm{s}\end{array}$} & \multicolumn{6}{|c|}{$\begin{array}{l}\text { Volume of tunnel } \\
V=13070 \mathrm{~m}^{3}\end{array}$} & \\
\hline
\end{tabular}

\section{Essential hydraulic head that must be assured by fans}

The fans must balance both distributed and concentrated fluid-dynamic load losses of flowing air of replacement with typical velocities of each $\mathrm{A}_{\mathrm{j}}$.

The procedure of computation is as follows:

\section{A. Distributed fluid-dynamic load losses}

- people detailed set $I_{j}$ of segments of tunnel owning same $A_{j}$ and $d_{j}$;

- the $\mathrm{l}_{\mathrm{ij}}$ length of each $\mathrm{T}_{\mathrm{i}}$ belonging to set $\mathrm{I}_{\mathrm{j}}$ is detailed;

- the length of each set $\mathrm{I}_{\mathrm{j}}$ is calculated using the formula: $\mathrm{l}_{\mathrm{j}}=\sum_{i=1}^{n_{j}} l_{i j}$, where $\mathrm{n}_{\mathrm{j}}=$ number of segment owning to set $\mathrm{I}_{\mathrm{j}}$;

- the "wet perimeter" of all cross-sections having $A_{j}$ and $d_{j}$ are calculated using the formula: $\mathrm{c}_{\mathrm{j}}=\frac{4 A_{j}}{d_{j}}$;

- by means of the experimental formula $\lambda_{\mathrm{j}}=0.026+\frac{0.0024}{c_{j}-0.48}$ [2], people calculated $\lambda_{j}=$ friction coefficient valid in the case of surfaces similar to that ones of tunnels;

- for every $A_{j}$, it is calculated ratio $r_{a j}$ between $\lambda_{j}$ and $d_{j}$ with $r_{a j}=\frac{\lambda_{j}}{d_{j}}\left[\frac{1}{m}\right]$;

- for every $A_{j}$, people considered $u_{j}=$ velocity of air able to assure $Q 1_{\text {min }}$;

- for every $A_{j}$, people computed sliding friction resistance $R_{a j}$ per "one meter of vertical fluid mass" using the formula: $R_{a j}=r_{a j} \frac{u_{j}^{2}}{2 g}$, where $\mathrm{g}=$ gravity acceleration; 
- for every set $\mathrm{I}_{\mathrm{j}}$, people computed distributed fluid-dynamic load losses $\Delta_{\text {pdj }}$ where $\Delta_{\mathrm{pdj}}=\mathrm{R}_{\mathrm{aj}} \mathrm{l}_{\mathrm{j}}$ (meter of vertical fluid mass);

- the global distributed fluid-dynamic load losses have been calculated with $\Delta_{\mathrm{pd}}$ $=\sum_{j=1}^{k} \Delta p_{d j}$ where $\mathrm{k}=$ number of cross-section $\mathrm{A}_{\mathrm{j}}$;

Table 5 shows example of computation of global distributed fluid-dynamic load losses for the "Turchio" tunnel.

Table 5: $\quad$ Global distributed fluid-dynamic load losses $\Delta_{\mathrm{pd}}$.

\begin{tabular}{|c|c|c|c|c|c|c|c|c|c|c|c|c|c|}
\hline & \multicolumn{13}{|c|}{ Turchio tunnels } \\
\hline & Seg. & $1_{i j}$ & $1_{j}$ & $A_{j}$ & $\mathrm{~d}_{\mathrm{j}}$ & $c_{j}$ & $\lambda_{j}$ & $\mathrm{r}_{\mathrm{aj}}$ & $u_{j}$ & $\mathrm{R}_{\mathrm{aj}}$ & $\Delta \mathrm{p}_{\mathrm{dj}}$ & $\Delta \mathbf{p}_{\mathrm{d}}$ & $\Delta \mathbf{p}_{\mathbf{d}}$ \\
\hline & & $(\mathrm{m})$ & $(\mathrm{m})$ & $\left(\mathrm{m}^{2}\right)$ & (m) & $(\mathrm{m})$ & & $(1 / \mathrm{m})$ & $(\mathrm{m} / \mathrm{s})$ & $\begin{array}{l}\text { m. } \\
\text { column } \\
\text { of fluid }\end{array}$ & $\begin{array}{l}\text { m. } \\
\text { column } \\
\text { of fluid }\end{array}$ & $\begin{array}{l}\text { m. } \\
\text { column } \\
\text { of fluid }\end{array}$ & (Pa) \\
\hline $\mathrm{I}_{2}$ & 5 & 45.28 & 45.28 & 2.83 & 1,56 & 7.26 & 0.0263 & 0.0168 & 1.50 & 0.0019 & 0.0877 & \multirow{7}{*}{2.498} & \multirow{7}{*}{30.626} \\
\hline $\mathrm{I}_{3}$ & $\begin{array}{l}1 \\
2 \\
3 \\
4 \\
6\end{array}$ & \begin{tabular}{|l}
45.44 \\
155.39 \\
163.06 \\
474.56 \\
23.40
\end{tabular} & 861.85 & 3.19 & 1.68 & 7.60 & 0.0263 & 0.0156 & 1.33 & 0.0014 & 1.2181 & & \\
\hline $\mathrm{I}_{4}$ & 0 & 1360 & 1360 & 4.09 & 1.75 & 9.35 & 0.0262 & 0.0150 & 1.04 & 0.0008 & 1.1254 & & \\
\hline $\mathrm{I}_{5}$ & $\begin{array}{l}7 \\
9\end{array}$ & $\begin{array}{l}41.88 \\
34.96\end{array}$ & 76.84 & 5.17 & 1.99 & 10.39 & 0.0262 & 0.0131 & 0.82 & 0.0004 & 0.0347 & & \\
\hline $\mathrm{I}_{6}$ & 8 & 75.25 & 75.25 & 6.60 & 2.25 & 11.73 & 0.0262 & 0.0116 & 0.64 & 0.0002 & 0.0183 & & \\
\hline $\mathrm{I}_{9}$ & 10 & 103.52 & 103.52 & 9.3 & 2.54 & 14.65 & 0.0261 & 0.0103 & 0.46 & 0.0001 & 0.0115 & & \\
\hline $\mathrm{I}_{15}$ & 11 & 58.84 & 58.84 & 15.73 & 3.45 & 18.238 & 0.0261 & 0.0075 & 0.27 & 0.0000 & 0.0016 & & \\
\hline & \multicolumn{5}{|c|}{$\begin{array}{l}\text { Acceleration of gravity } \mathrm{g}=9.81 \\
\mathrm{~m} / \mathrm{s}^{2}\end{array}$} & \multicolumn{4}{|c|}{$\begin{array}{l}\text { Density wet air } \rho_{\mathrm{a} . \mathrm{u}}=1.25 \\
\mathrm{~kg} / \mathrm{m}^{3}\end{array}$} & \multicolumn{3}{|c|}{$\begin{array}{l}\text { Minimum flow rate } \\
\mathrm{Q}_{1 \min }=4.25 \mathrm{~m}^{3} / \mathrm{s} \\
\end{array}$} & \\
\hline
\end{tabular}

\section{B. Concentrated fluid-dynamic load losses}

Such losses are function of geometrical characteristics here after reported:

- Changing of direction following the length of tunnels

- Sudden changing of area of cross-sections along every segment $\mathrm{T}_{\mathrm{i}}$

- Areas of cross-sections

The concentrated fluid-dynamic load losses have been calculated with formula: $\Delta \mathrm{p}_{\mathrm{cij}}=\frac{\Delta p_{d i j}}{(x \%)_{i j}}$ where $(\mathrm{x} \%)_{\mathrm{ij}}$ is percentage parameters coming from previous reported characteristics and from previous planning knowledge of the authors. The values are showed in Table 6.

Table 6: Percentage parameter $\mathrm{x} \%$ j.

\begin{tabular}{|c|c|c|}
\hline Class of section $\mathbf{C}_{\mathbf{j}}$ & Without changing of direction & With change of direction and cross-section \\
\hline$\left(\mathrm{m}^{2}\right)$ & & \\
\hline$[15 ; 16[$ & 0.90 & 0.85 \\
\hline$[9 ; 10[$ & 0.85 & 0.80 \\
\hline$[6 ; 7[$ & 0.80 & 0.75 \\
\hline$[5 ; 6[$ & 0.75 & 0.70 \\
\hline$[4 ; 5[$ & 0.70 & 0.65 \\
\hline$[3 ; 4[$ & 0.65 & 0.60 \\
\hline$[2 ; 3[$ & 0.60 & 0.55 \\
\hline
\end{tabular}


An example of global concentrated fluid-dynamic load losses, shown in Table 7 , was calculated with the formula $\Delta \mathrm{p}_{\mathrm{c}}=\sum_{i=1}^{n} \Delta p_{c i j}$.

Table 7: $\Delta \mathrm{p}_{\mathrm{c}}$ for Turchio tunnels.

\begin{tabular}{|c|c|c|c|c|c|c|c|c|c|c|c|c|c|c|}
\hline \multicolumn{15}{|c|}{ Turchio tunnels } \\
\hline Seg. & $\mathrm{i}_{\mathrm{ij}}$ & $A_{j}$ & $\mathrm{~d}_{\mathrm{j}}$ & $c_{j}$ & $\lambda_{\mathrm{j}}$ & $\mathrm{r}_{\mathrm{aj}}$ & $u_{j}$ & $\mathrm{R}_{\mathrm{aj}}$ & $\Delta \mathrm{p}_{\mathrm{dij}}$ & \begin{tabular}{|c|} 
Change \\
of \\
direction \\
or areas \\
\end{tabular} & $\mathrm{x}_{\mathrm{ij}} \%$ & $\Delta \mathrm{p}_{\mathrm{cij}}$ & $\Delta p_{c}$ & $\Delta p_{c}$ \\
\hline & (m) & $\left(\mathrm{m}^{2}\right)$ & $(\mathrm{m})$ & (m) & & $(1 / \mathrm{m})$ & $(\mathrm{m} / \mathrm{s})$ & $\begin{array}{l}\text { m. } \\
\text { column } \\
\text { of fluid }\end{array}$ & $\begin{array}{l}\text { m. } \\
\text { column } \\
\text { of fluid }\end{array}$ & & & $\begin{array}{l}\text { m. } \\
\text { column } \\
\text { of fluid }\end{array}$ & $\begin{array}{l}\text { m. } \\
\text { column } \\
\text { of fluid }\end{array}$ & (Pa) \\
\hline 0 & 1360 & 4.09 & 1.75 & 9.35 & 0.0262 & 0.0150 & 1.04 & 0.0008 & 1.1254 & yes & 0.65 & 1.7315 & \multirow{12}{*}{3.988} & \multirow{12}{*}{48.907} \\
\hline 1 & 45.44 & 3.19 & 1.68 & 7.60 & 0.0263 & 0.0156 & 1.33 & 0.0014 & 0.0642 & yes & 0.60 & 0.1070 & & \\
\hline 2 & 155.39 & 3.19 & 1.68 & 7.60 & 0.0263 & 0.0156 & 1.33 & 0.0014 & 0.2196 & yes & 0.60 & 0.3660 & & \\
\hline 3 & 163.06 & 3.19 & 1.68 & 7.60 & 0.0263 & 0.0156 & 1.33 & 0.0014 & 0.2304 & yes & 0.60 & 0.3841 & & \\
\hline 4 & 474.56 & 3.19 & 1.68 & 7.60 & 0.0263 & 0.0156 & 1.33 & 0.0014 & 0.6707 & yes & 0.60 & 1.1179 & & \\
\hline 5 & 45.28 & 2.83 & 1.56 & 7.26 & 0.0263 & 0.0168 & 1.50 & 0.0019 & 0.0877 & no & 0.60 & 0.1462 & & \\
\hline 6 & 23.40 & 3.19 & 1.68 & 7.60 & 0.0263 & 0.0156 & 1.33 & 0.0014 & 0.0330 & no & 0.65 & 0.0508 & & \\
\hline 7 & 41.88 & 5.17 & 1.99 & 10.39 & 0.0262 & 0.0131 & 0.82 & 0.0004 & 0.0189 & no & 0.75 & 0.0252 & & \\
\hline 8 & 75.25 & 6.60 & 2.25 & 11.73 & 0.0262 & 0.0116 & 0.64 & 0.0002 & 0.0183 & no & 0.80 & 0.0228 & & \\
\hline 9 & 34.96 & 5.17 & 1.99 & 10.39 & 0.0262 & 0.0131 & 0.82 & 0.0004 & 0.0158 & no & 0.75 & 0.0210 & & \\
\hline 10 & 103.52 & 9.3 & 2.54 & 14.65 & 0.0261 & 0.0103 & 0.46 & 0.0001 & 0.0115 & no & 0.85 & 0.0135 & & \\
\hline 11 & 58.84 & 15.73 & 3.45 & 18.24 & 0.0261 & 0.0075 & 0.27 & 0.0000 & 0.0016 & yes & 0.85 & 0.0019 & & \\
\hline \multicolumn{6}{|c|}{ Acceleration of gravity $\mathrm{g}=9.81 \mathrm{~m} / \mathrm{s}^{2}$} & \multicolumn{5}{|c|}{ Density wet air $\rho_{a u}=1.25 \mathrm{~kg} / \mathrm{m}^{3}$} & & & & \\
\hline
\end{tabular}

\section{Global fluid-dynamic load losses}

- The global losses for each $\mathrm{T}_{\mathrm{ij}}$ of cross-section $\mathrm{A}_{\mathrm{j}}$ is produced by the sum of "distributed" and "concentrated" by $\Delta \mathrm{p}_{\mathrm{tij}}=\Delta \mathrm{p}_{\mathrm{dij}}+\Delta \mathrm{p}_{\mathrm{cij}}$;

- The global losses for each whole tunnel are computed by $\Delta \mathrm{p}=\sum_{i=1}^{n} \Delta p_{T i j}$ and example of global $\Delta \mathrm{p}$ is shown in Table 8 .

Table 8: $\quad$ Fluid-dynamic global losses $\Delta$ p check of suitability of fans in Sidra's depository.

\begin{tabular}{|c|c|c|c|c|c|c|c|}
\hline \multicolumn{8}{|c|}{ Turchio tunnels } \\
\hline Segment & $1_{i j}$ & $\Delta \mathrm{p}_{\mathrm{dij}}$ & $\Delta \mathrm{p}_{\mathrm{cij}}$ & $\Delta \mathrm{p}_{\mathrm{dij}}$ & $\Delta \mathrm{p}_{\mathrm{cij}}$ & $\Delta \mathrm{p}_{\mathrm{ij}}$ & $\Delta p$ \\
\hline & (m) & $\begin{array}{c}\mathrm{m} . \\
\text { column }\end{array}$ & $\begin{array}{c}\text { m. } \\
\text { column }\end{array}$ & $(\mathrm{Pa})$ & $(\mathrm{Pa})$ & $(\mathrm{Pa})$ & (Pa) \\
\hline 0 & 1360 & 1.125483 & 1.731512 & 13.801235 & 21.232666 & 35.033901 & \multirow{12}{*}{79.533} \\
\hline 1 & 45.44 & 0.064225 & 0.107042 & 0.787559 & 1.312603 & 2.100162 & \\
\hline 2 & \begin{tabular}{|l|}
155.39 \\
\end{tabular} & 0.219629 & 0.366048 & 2.693201 & 4.488664 & 7.181864 & \\
\hline 3 & 163.06 & 0.230470 & 0.384116 & 2.826138 & 4.710222 & 7.536361 & \\
\hline 4 & 474.56 & 0.670745 & 1.117908 & 8.225011 & 13.708347 & 21.933357 & \\
\hline 5 & 45.28 & 0.087723 & 0.146205 & 1.075703 & 1.792839 & 2.868542 & \\
\hline 6 & 23.40 & 0.033074 & 0.050883 & 0.405570 & 0.623953 & 1.029523 & \\
\hline 7 & 41.88 & 0.018927 & 0.025236 & 0.232092 & 0.309456 & 0.541549 & \\
\hline 8 & 75.25 & 0.018302 & 0.022878 & 0.224428 & 0.280541 & 0.504970 & \\
\hline 9 & 34.96 & 0.015800 & 0.021066 & 0.193748 & 0.258322 & 0.452069 & \\
\hline 10 & 103.52 & 0.011503 & 0.013533 & 0.141056 & 0.165948 & 0.307004 & \\
\hline 11 & 58.84 & 0.001656 & 0.001948 & 0.020307 & 0.023887 & 0.044194 & \\
\hline \multicolumn{4}{|c|}{ Acceleration of gravity $\mathrm{g}=9.81 \mathrm{~m} / \mathrm{s}^{2}$} & \multicolumn{3}{|c|}{ Density wet air $\rho_{\text {a.u. }}=1.25 \mathrm{~kg} / \mathrm{m}^{3}$} & \\
\hline
\end{tabular}


Using the values $\mathrm{Q}_{\operatorname{minTA}}=4.20 \mathrm{~m}^{3} / \mathrm{s}$ (Tavolone) and $\mathrm{Q}_{\operatorname{minTU}}=4.25 \mathrm{~m}^{3} / \mathrm{s}$ (Turchio), as reported in previous tables where global losses $\Delta \mathrm{p}_{\mathrm{TA}}=73.730[\mathrm{~Pa}]$ for Tavolone and $\Delta \mathrm{p}_{\mathrm{TU}}=79.533[\mathrm{~Pa}]$ for Turchio, people selected fans of different powers owned by Sidra Ltd. and positioned them for each tunnels as shown in fig. 5 (Turchio).

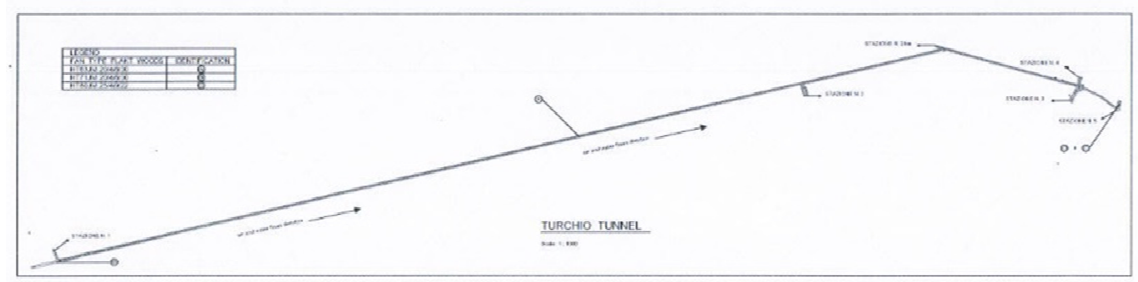

Figure 5: Positions of fans in Turchio's plan.

\section{Next activities for the research group}

The group of researchers will carry out the following activities :

- Coordination of installation of fans as indicated in fig. 5: expected end of installation within the 07.30.2015.

- Coordination of installation of network of sensors of Rn's concentration and electronic system of control: expected end of works 09.30.2015.

- After fans and control system will be installed, than it will start scientific and technical checks reported hereafter:

- Check of air velocity during renewal of indoor air to ensure the generic correspondence between the air velocity at the base of computation and the real air velocity reached by means of fans.

- Check of the greatest times of global renewal of air to ensure the compatibility with times of staying of workers in tunnels.

- Trend of decrease of Rn's concentrations during time of work of fans: $\rho_{\mathrm{Rn}}=\mathrm{f}(\tau)$

○ Daily electrical energy consumption caused by mode of operation of fans.

\section{Conclusion}

The future experimental campaigns of Rn measurements, after the assembling of fans in tunnels, will allow for attempts to calibrate an electronic system of control and to characterize a hydraulic head $(\Delta \mathrm{p})$ that fans must supply in function of achievement of the lowest $\mathrm{Rn}$ concentrations $\left(\rho_{\mathrm{Rnmin}}\right)$, which are required by planning, to detail the empirical real operational curves of fans (function of $\tau$ and $\rho_{\text {Rnmin }}$ ) with an aim to save the biggest amount of electrical energy wasted by fans. People will exhibit the results of the next activities and goals achieved in the next Air Pollution Conference. 


\section{References}

[1] Patania F., Gagliano A., Nocera F., "Radon pollution dynamic in indoor environment: proposal about its control", International Conference on Healthy Building, August 1994, Budapest, Hungary.

[2] H. Geiger and K. Schee, "Handbuch der Physik", Series Ed.: Flügge,S., ISSN 0085-140x. 